\title{
A study of physical activity levels of pregnant women using the Polish version of Pregnancy Physical Activity Questionnaire (PPAQ-PL)
}

\author{
Katarzyna Zdzislawa Antosiak-Cyrak ${ }^{1}$, Anna Demuth ${ }^{2}$ \\ ${ }^{1}$ Department of Swimming and Water Rescue, University School of Physical Education in Poznan, Poland \\ ${ }^{2}$ Department of Anthropology and Biometry, University School of Physical Education in Poznan, Poland
}

\begin{abstract}
Objectives: The aim of the present study was to determine the optimal level of physical activity during pregnancy and discuss whether and to what extent biological, social and demographic variables affect the level of total physical activity in studied women.

Material and methods: The respondents were 267 pregnant women from Poland aged $28.16 \pm 4.67$ years. The majority of women under study had a higher and a secondary education and lived in villages near Poznań, i.e. a large urban agglomeration in Poland. Most of the women were in the first or second pregnancies, at the mean gestational age of 24th week. The study used the Polish version of PPAQ questionnaire to determine the weekly energy expenditure (MET hour/week -1) (Krzepota, Sadowska 2017). The respondents self-assessed their physical activity levels by filling in a questionnaire consisting of 33 items grouped into the following activity categories: household/caregiving (15 items), occupational (5 items), sports/exercises (7-9 items), transportation ( 3 items), and inactivity ( 3 items).

Results: Pregnant women prefer physical exercises of low and moderate intensity. The test results indicated a significant impact of variables such as age, trimester of pregnancy, and number (sequence) of pregnancies on the women's physical activity.

Conclusions: The results of the present study confirm that actions propagating active lifestyles among pregnant women are necessary. It also appears that the recommendations of the Polish Society of Gynecologists and Obstetricians regarding the physical activity of pregnant and postnatal women require adjustments and improvements.

Key words: physical activity; pregnancy; pregnancy outcomes; excessive weight gain
\end{abstract}

Ginekologia Polska 2019; 90, 5: 250-255

\section{INTRODUCTION}

The results of epidemiological studies from a number of countries have confirmed beneficial effects of physical activity during pregnancy on the mother's and child's health $[1,2]$. Regular physical exercises were shown to have a positive impact on cardiovascular endurance, lower the risk of excessive body weight gain [3], relieve spinal pains, and reduce depressive symptoms during pregnancy [4] and after childbirth as well as contribute to regaining proper body weight after childbirth. Increased physical activity during pregnancy is also associated with a lower risk of caesarean delivery [5], respiratory diseases, and macrosomia in newborns. Physical activity greatly influences the development of cognitive abilities in unborn children, preventing SI (Sensory Integration) disorders. Furthermore, physical exercises during pregnancy have a positive effect on the woman's blood pressure, and cholesterol and glucose levels. They also improve sleep quality. However, recommendations regarding the types, intensity and duration of physical activity during pregnancy may invoke certain controversies.

Research teams from different countries have attempted to estimate the optimal volume of physical activity for pregnant women using different methods and techniques. Krzepota and Sadowska [6] noted that the determination of the type, duration and intensity of physical activity during pregnancy is key to the health condition of pregnant women. Insufficient physical activity will not produce desired physiological effects, while excessive exercise unadjusted for age, health status, and physical capabilities, can be even harmful.

Evenson et al. [7] in their review Guidelines for Physical Activity during Pregnancy:Comparisons From Around the World indicated the fundamental differences in the assessment 
of physical activity levels of pregnant women. Their comparison of national sets of recommendations from eleven countries revealed that the differences mainly concerned contraindications to physical exercise, general training exercise guidelines, including the form and intensity of physical activity, both recommended and not recommended. In fact, the number of studies in this area appear to be rather insignificant.

The recommendations of the Polish Society of Gynecologists and Obstetricians [8] regarding physical activity during physiological pregnancy focus on the outcome of exercises of excessive intensity and volume. Hazards to the fetus may include disorders of maternal-placental circulation, hyperthermia, dehydration, limited maternal-fetal exchange, and growth disorders. On the other hand, exercising pregnant mothers may be susceptible to traumas, fatigue, fainting, and loosening of the joints (especially of the spine). These recommendations do not encourage physicians to propagate physical exercises among pregnant women.

Another problem is the lack of uniform and standardized research tools. In Poland, despite numerous publications examining the levels of physical activity of pregnant women, there have been very few studies using standardized measurement tools, e.g. Wojtyła [9], Krzepota [6], Suliga [10]. Those authors made use of the Pregnancy Physical Activity Questionnaire (PPAQ) Chasan-Taber [11]. PPAQ has been transculturally adapted for Vietnamese [12], Japanese $[13,14]$, French [15], Turkish [16] and Polish [6, 10] populations. It can serve as a uniform criterion for measurement of physical activity of pregnant women that can be used for a comparative analysis considering cultural differences.

\section{Objectives}

The aim of the present study was to determine the optimal level of physical activity during pregnancy and discuss whether and to what extent biological, social and demographic variables affect the level of total physical activity in studied women.

\section{MATERIAL AND METHODS}

The respondents were pregnant women from Poland aged $28.16 \pm 4.67$ years, the majority of whom were in the age range of 25 to 35 years. The majority of women under study had a higher and a secondary education $(52 \%$ and $33 \%$, respectively) and lived in villages near Poznań, i.e. a large urban agglomeration in Poland. Most of the women were in the first or second pregnancies, at the mean gestational age of $24^{\text {th }}$ week (Tab. 1).

The study used the Polish version of PPAQ questionnaire to determine the weekly energy expenditure (MET hour/week -1) [6]. The respondents self-assessed their physical activity levels by filling in a questionnaire consisting of 33 items grouped into the following activity categories: household/caregiving (15 items), occupational (5 items), sports/exercises (7-9 items), transportation ( 3 items), and inactivity ( 3 items). The declared duration of performance of particular tasks was assigned fixed numbers of minutes $(0 ; 0.12 ; 0.50 ; 1.0 ; 2.0 ; 3.0)$ and then multiplied by the number of days of performance of tasks per week [6]. The obtained values were then multiplied by intensity (MET) in accordance with the guidelines in "Compendium of Physical Activities: an update of activity codes and MET intensities" [16]. The following activity intensity ranges were used: sedentary < $1.5 \mathrm{METs}$; light $1.5-<3.0 \mathrm{METs}$; moderate $\geq 3.0-\leq 6.0 \mathrm{METs}$; and vigorous $>6.0 \mathrm{METs}$

\section{Etical approval}

The study has been approved by Poznan Medical University Ethical Committee.

\begin{tabular}{|c|c|c|c|c|c|}
\hline \multicolumn{2}{|l|}{ Variable } & Total & $1^{\text {st }}$ trimester & $2^{\text {nd }}$ trimester & $3^{\text {rd }}$ trimester \\
\hline \multicolumn{2}{|c|}{ Number of pregnant women [n/\%] } & 267 & $48 / 18$ & $113 / 42$ & $106 / 40$ \\
\hline \multicolumn{2}{|l|}{ Age [years] } & 28.16 & 28.17 & 27.29 & 29.08 \\
\hline \multirow{3}{*}{ Education [\%] } & higher & 51.82 & 29.03 & 43.86 & 65.71 \\
\hline & secondary & 42.73 & 64.52 & 38.64 & 28.57 \\
\hline & vocation & 5.45 & 6.45 & 4.55 & 5.71 \\
\hline \multirow{2}{*}{ Place of residence [\%] } & city & 29.09 & 25.81 & 53.13 & 21.88 \\
\hline & country & 70.91 & 29.49 & 34.62 & 35.90 \\
\hline \multicolumn{2}{|l|}{ Week of pregnancy (in months) } & 24.22 & 9.96 & 21.58 & 33.04 \\
\hline \multirow{3}{*}{ Sequence of pregnancies [\%] } & first & 50.00 & 19.28 & 50.60 & 30.12 \\
\hline & second & 42.17 & 12.86 & 42.86 & 44.29 \\
\hline & $\geq$ third & 7.83 & 36.36 & 36.36 & 28.47 \\
\hline
\end{tabular}




\section{RESULTS}

By using the Kruskal-Wallis test by ranks and the Mann-Whitney U test (Tab. 2) the authors determined first whether and to what extent socio-demographic and biological variables affected the women's total physical activity. The test results indicated a significant impact of variables such as age, trimester of pregnancy, and number (sequence) of pregnancies on the women's physical activity.

Next the women's physical activities were compared with regard to type and intensity of exercise. The highest percentage of women reported undertaking light and moderate physical activity (Tab. 3). No woman in the third trimester of pregnancy reported vigorous physical activity (>6.0 MET) or activities associated with occupation or transportation. The respondents revealed the highest physical activity levels in the household category and the lowest in the transportation category. The mean sports activity of studied women amounted to $12.929 \mathrm{MET}$ h/week and constituted $6 \%$ of total physical activity. Furthermore, the intensity of undertaken activities in each trimester of pregnancy decreased; however, significant differences were only found in total physical activity ( $p \leq 0.0463)$ and light physical

Table 2. Kruskal-Wallis test and Mann-Whitney $\mathrm{U}$ test results for levels of total physical activity with regard to socio-biological variables

\begin{tabular}{|l|l|l|}
\hline variable & $\begin{array}{l}\text { Kruskal-Wallis test } \\
\text { Mann-Whitney U test }\end{array}$ & $\boldsymbol{p}$ value \\
\hline Age & 8.13 & $\mathbf{0 . 0 1 7 1}$ \\
\hline Pregnancy trimester & 6.15 & $\mathbf{0 . 0 4 6 3}$ \\
\hline Sequence of pregnancies & 24.04 & $\mathbf{0 . 0 0 0 0}$ \\
\hline Education & 3.02 & 0.2150 \\
\hline Place of residence & 0.35 & 0.7248 \\
\hline
\end{tabular}

Values in bold are statistically significant activity ( $p \leq 0.0247)$. At the same time, lower occupational and household activity levels in the consecutive pregnancy trimesters were found, with statistically significant differences only in the former activity category $(p \leq 0.000)$.

The analysis of relationships between the sequence of pregnancies and the level of physical activity produced interesting results (Tab. 4). It was revealed that the sequence of pregnancies affected significantly the women's total physical activity as well as their sedentary, light, moderate, household activities and inactivity (passive recreation). Women in their second pregnancy displayed the highest levels of total, light, moderate, occupational and household physical activity. Ad hoc comparisons showed that out of the five studied activity categories four were at significant levels in women in their second pregnancy. Furthermore, women in their third and subsequent pregnancies featured a significantly lower level of sedentary activity, and spent less time on passive recreation (inactivity) compared to women in their first and second pregnancies.

A factor significantly affecting the pregnant women's total physical activity was their age. A thorough analysis (ad hoc comparison) showed that age significantly differentiated only the total physical activity levels $(H=8.13 ; \mathrm{p}=0.0171)$ and occupational activity levels $(H=8.73 ; p=0.0127)$ of studied pregnant women. Despite the significant correlation (coefficient of correlation $r=0.14 ; p=0.0184$ ) women's age only insignificantly (coefficient of determination $\mathrm{R}^{2}=0.4$; $p \leq 0.01$ ) contributed to the variability of total physical activity levels.

\section{DISCUSSION}

There have been very few Polish studies utilizing standardized research tools for assessing the level of physical activity of pregnant women. There is no research considering the frequency, duration, and type of physical activity

\begin{tabular}{|c|c|c|c|c|c|c|c|c|}
\hline \multicolumn{3}{|c|}{ Types of physical activity } & Total & $1^{\text {st }}$ trimester & $2^{\text {nd }}$ trimester & $3^{\text {rd }}$ trimester & Kruskal-Wallis test & p value \\
\hline \multicolumn{3}{|c|}{ Total physical activity } & 213.17 & 265.69 & 202.43 & 186.28 & 6.15 & 0.0463 \\
\hline \multirow{9}{*}{$\begin{array}{l}\text { Physical } \\
\text { activity }\end{array}$} & \multirow{4}{*}{ by intensity } & sedentary & 40.18 & 40.26 & 38.43 & 44.10 & 1.39 & 0.4990 \\
\hline & & light & 89.49 & 112.76 & 84.99 & 79.78 & 7.40 & 0.0247 \\
\hline & & moderate & 68.38 & 99.10 & 62.81 & 40.13 & 1.93 & 0.3814 \\
\hline & & vigorous & 1.65 & 1.48 & 1.39 & 0 & 3.71 & 0.1561 \\
\hline & \multirow{5}{*}{ by type } & household & 112.00 & 123.24 & 114.91 & 88.81 & 0.21 & 0.9016 \\
\hline & & occupational & 29.83 & 78.57 & 17.20 & 0 & 25.33 & 0.0000 \\
\hline & & sports & 12.92 & 9.24 & 12.85 & 9.375 & 5.11 & 0.0779 \\
\hline & & transportation & 3.61 & 1.26 & 2.958 & 0 & 5.34 & 0.0729 \\
\hline & & inactivity & 54.81 & 53.39 & 54.51 & 53.55 & 0.43 & 0.8067 \\
\hline
\end{tabular}

Values in bold are statistically significant 


\begin{tabular}{|c|c|c|c|c|c|c|c|}
\hline \multicolumn{3}{|c|}{ Physical activity } & $\begin{array}{l}\text { First } \\
\text { pregnancy }\end{array}$ & $\begin{array}{l}\text { Second } \\
\text { pregnancy }\end{array}$ & $\begin{array}{l}\text { Third and } \\
\text { subsequent } \\
\text { pregnancies }\end{array}$ & Kruskal-Wallis test & P value \\
\hline \multicolumn{3}{|c|}{ Total physical activity } & 186.93 & 263.95 & 209.66 & 24.04 & 0.0000 \\
\hline \multirow{9}{*}{$\begin{array}{l}\text { Physical } \\
\text { activity }\end{array}$} & \multirow{4}{*}{ by intensity } & sedentary & 42.41 & 39.06 & 30.64 & 7.23 & 0.0270 \\
\hline & & light & 74.44 & 113.86 & 102.13 & 36.66 & 0.0000 \\
\hline & & moderate & 53.22 & 97.66 & 66.48 & 27.39 & 0.0000 \\
\hline & & vigorous & 1.58 & 1.98 & 0.96 & 3.59 & 0.1658 \\
\hline & \multirow{5}{*}{ by type } & household & 78.93 & 163.64 & 145.53 & 73.89 & 0.0000 \\
\hline & & occupational & 29.69 & 35.13 & 14.30 & 1.54 & 0.4627 \\
\hline & & sports & 14.49 & 11.86 & 7.07 & 4.58 & 0.1012 \\
\hline & & transportation & 4.82 & 1.89 & 1.85 & 3.09 & 0.2130 \\
\hline & & inactivity & 59.00 & 51.43 & 40.91 & 14.27 & 0.0000 \\
\hline
\end{tabular}

Values in bold are statistically significant

focusing on how these variables change during pregnancy. Very few publications have focused on relations between biological and social factors and the level of physical activity of pregnant women. The present study is an attempt to fill this void.

Research results show that pregnant women are less physically active than non-pregnant women, and that pregnancy leads to a decrease in physical activity [17]. Moreover, women have a tendency to reduce the volume, duration, and intensity of physical exercise during pregnancy [18, 19]. The level of physical activity of pregnant women is usually assessed as low [20].

In our study low (light) physical activity (<600 METs) was characteristic of $91.2 \%$ of studied pregnant women, moderate physical activity (600-1500 METs) of $8.8 \%$, and no woman under study displayed a vigorous level of physical activity. Thus in comparison with results of other Polish authors, the level of total physical activity of pregnant women in the present study (213.17 MET) was slightly lower than in Krzepota and Sadowska [6] — 246.41 MET, but higher than in Wojtyła [9] - 190.83 MET. The studied women featured a higher contribution of moderate-intensity exercise (3.0-6.0 MET), and lower contribution of sedentary physical activity ( $<1.5 \mathrm{METs}$ ), compared with women studied by other Polish authors. The women from Poznań spent less time watching TV or video movies, reading or making job unrelated telephone calls than women studied by Wojtyła [9], Krzepota [6] and Suliga [10].

Experts indicate that pregnant women tend to replace moderate-intensity exercises with low-intensity sedentary exercises [21]. A review of Polish literature revealed that lower levels of education were associated with a lower interest of Polish society in sports and recreational forms of leisure [22]. Similar results were produced in the 2009 Eurobarometer [23] survey conducted among 26788 citizens of $27 \mathrm{EU}$ member states. The survey revealed a strong correlation between education and frequency of undertaking active leisure. 64\% of persons who completed their education at the age of 15 were shown to have never undertaken regular physical activity. The respective percentages were $39 \%$ of those who finished their education at the age of 16-19 years, and $24 \%$ of those who completed their education at the age of 20 years and above. The Eurobarometer survey authors postulated that a higher education level was associated with a better standard of living, and that better educated EU citizens associated physical fitness with better quality of life. In the present study most women had a higher and secondary education, which could have significantly affected the level of their total physical activity that was higher than the level of physical activity of pregnant women in other studies using the same assessment tool (Tab. 5). It can be suggested that research designs should consider biological and socio-demographic factors that can significantly affect the level of physical activity.

The present study also revealed a disturbing tendency of decreasing physical activity levels in the later trimesters of pregnancy. Significant differences were found in total physical activity level in the first and second trimesters, and in low-intensity activity level in all trimesters. Although the respondents were not asked to provide reasons for cessation of exercising, the observed decrease in physical activity in the second and the third trimesters of pregnancy can be related to women's mood changes and fetal growth which leads to gaining weight and discomforts such as back pain, fatigue, and sleeplessness [24, 25]. As indicated by other authors decreased physical activity can also result from the lack of exercising habits related to the development of the awareness of physical activity. Experts propose that 
Table 5. Comparison of study results by different authors

\begin{tabular}{|l|l|l|l|l|l|}
\hline Activity & $\begin{array}{l}\text { Authors' own research } \\
\mathbf{( 2 0 1 8 )} \\
\text { Polish } \\
\mathbf{N}=\mathbf{2 6 7}\end{array}$ & $\begin{array}{l}\text { Wojtyła } \\
\mathbf{( 2 0 1 2 )} \\
\text { Polish } \\
\mathbf{N = 2 8 5 2}\end{array}$ & $\begin{array}{l}\text { Suliga } \\
\mathbf{( 2 0 1 7 )} \\
\text { Polish } \\
\mathbf{N}=\mathbf{1 6 4}\end{array}$ & $\begin{array}{l}\text { Chandonnet } \\
\mathbf{( 2 0 1 2 )} \\
\text { French } \\
\mathbf{N}=\mathbf{4 9}\end{array}$ & $\begin{array}{l}\text { Ota } \\
\text { (2008) } \\
\text { Vietnamese } \\
\mathbf{N}=\mathbf{6 0}\end{array}$ \\
\hline Total activity & $213.17 \pm 167.42$ & 190.83 & no data & 180.00 & 137.97 \\
\hline Sedentary & $40.18 \pm 27.98$ & 59.50 & 60.70 & 60.00 & 28.00 \\
\hline Light & $89.49 \pm 36.36$ & 83.65 & 44.10 & 73.00 & 119.70 \\
\hline Moderate & $68.38 \pm 129.33$ & 31.75 & 20.40 & 34.00 & 3.10 \\
\hline Vigorous & $1.65 \pm 92.66$ & 0 & 0.80 & 0 & 0 \\
\hline Household/caregiving & $78.93 \pm 95.96$ & 142.54 & 72.70 & 74.00 & 11.30 \\
\hline Occupational & $29.69 \pm 30.24$ & 0 & 37.00 & 0 & 0 \\
\hline Sports/exercises & $14.49 \pm 122.16$ & 20.13 & 6.80 & 11.00 & 0.60 \\
\hline Transportation & $4.82 \pm 29$ & 0 & 9.50 & 14.00 & 2.80
\end{tabular}

women who led a physically active lifestyle before becoming pregnant, should not abandon their active lifestyle habits but only modify them. The intensity and type of exercises should be adjusted for pregnancy trimester and woman's general disposition. During physiological pregnancy with no complications, medical professionals see no contraindications to undertaking physical activity during pregnancy. Healthy women should begin or continue moderate-intensity aerobic activity during pregnancy, accumulating at least 150 minutes per week. [3, 26, 27]. The most beneficial forms of physical activity for pregnant women are walking, gymnastics, yoga, and swimming.

Experts also point to the fact that a decrease in physical activity during pregnancy can be noted in the performance of physical exercises as well as activities of daily living such as household chores, caregiving, transportation, and occupational activities. Research shows that undertaking physical activity during pregnancy has a significant influence on women's self-assessment of the course of the pregnancy and on their life satisfaction [28]. Non-employed women and pregnant women on sick leave experience health problems much more often. Professionally active women cope with emotional problems more effectively, feel stronger, have a higher self-esteem, and display greater physical endurance. They also recover faster and are more resourceful in their daily living (Nowakowska-Głąb, Maniecka-Bryła 2012). On the other hand, very intensive and intensive professional activities negatively affect intrauterine fetal development and contribute to a decrease in newborns' birthweight [29]. In the present study the highest levels of occupational activity were found in women in the first trimester of pregnancy. In the second trimester the level of occupational activity was significantly lower, and in the third trimester no women undertook any professional activities.

The above results appear to be very disturbing. The pregnant women under study prefer low- and moderate-in- tensity exercises, while their level of total physical activity is slightly higher than in respondents from other studies. These results could have been affected by the women's higher education level than in women studied by other authors. On the other hand, the study groups evaluated by other researchers were not that numerous (except for Wojtyła et al.). It was rather difficult to find comparable studies in Polish literature The available research data on the physical activity of pregnant women are spotty and inconsistent, and often based on various authors' own questionnaires. This makes any solid comparative analysis of results rather difficult. There is a pressing need to develop and implement the educational component of maternity care, increase pregnant women's motivation to take up physical exercises, and modify and adjust relevant recommendations of the Polish Society of Gynecologists and Obstetricians.

\section{CONCLUSIONS}

1. Pregnant women prefer physical exercises of low and moderate intensity. The research results show that only biological variables, i.e. age, trimester, (number) sequence of pregnancies, significantly affect pregnant women's level of total physical activity.

2. The general awareness of benefits of physical activity is not enough to encourage women to take up physical exercises during pregnancy. The results of the present study confirm that actions propagating active lifestyles among pregnant women are necessary.

3. The results of the present multi-characteristic analysis can be used to define the approaches for maternity care and healthcare professionals and institutions to raise the awareness of benefits of physical activity for the course of pregnancy and fetal development.

4. A prospective thorough analysis of physical activity of pregnant women will require designing an extra questionnaire that would include items related to respond- 
ents' pre-conception health behaviors (e.g. physical activity, sport career); socio-demographic data (occupation, education, marital status, number of children); and pre-conception body height and body weight.

\section{REFERENCES}

1. Downs DS, Chasan-Taber L, Evenson KR, et al. Physical activity and pregnancy: past and present evidence and future recommendations. Res $Q$ Exerc Sport. 2012; 83(4): 485-502, doi: 10.1080/02701367.2012.10599 138, indexed in Pubmed: 23367811.

2. Nascimento SL, Surita FG, Parpinelli MÂ, et al. The effect of an antenatal physical exercise programme on maternal/perinatal outcomes and quality of life in overweight and obese pregnant women: a randomised clinical trial. BJOG. 2011; 118(12): 1455-1463, doi: 10.1111/j.1471-0528. 2011.03084.x, indexed in Pubmed: 21895947.

3. Mizgier M, Mruczyk K, Jarząbek-Bielecka G, et al. The impact of physical activity during pregnancy on maternal weight and obstetric outcomes. Ginekol Pol. 2018; 89(2): 80-88, doi: 10.5603/GP.a2018.0014, indexed in Pubmed: 29512812.

4. Szegda K, Bertone-Johnson ER, Pekow P, et al. Physical activity and depressive symptoms during pregnancy among Latina women: a prospective cohort study. BMC Pregnancy Childbirth. 2018; 18(1): 252, doi: 10.1186/s12884-018-1839-5, indexed in Pubmed: 29925325.

5. Tinloy J, Chuang $\mathrm{CH}$, Zhu J, et al. Exercise during pregnancy and risk of late preterm birth, cesarean delivery, and hospitalizations. Womens Health Issues. 2014; 24(1): e99-e9e104, doi: 10.1016/j.whi.2013.11.003, indexed in Pubmed: 24439953.

6. Krzepota J, Sadowska D. Kwestionariusz aktywności fizycznej kobiet w ciąży - wersja polska (PPAQ-PL). Medycyna Ogólna i Nauki o Zdrowiu. 2017; 23(2): 100-106.

7. Evenson KR, Barakat R, Brown WJ, et al. Guidelines for Physical Activity during Pregnancy: Comparisons From Around the World. Am J Lifestyle Med. 2014; 8(2): 102-121, doi: 10.1177/1559827613498204, indexed in Pubmed: 25346651.

8. Polskie Towarzystwo Ginekologiczne. Rekomendacje Polskiego Towarzystwa Ginekologicznego w zakresie opieki przedporodowej w ciaży o prawidłowym przebiegu 20-21.05.2005.

9. Wojtyła A, Kapka-Skrzypczak L, Paprzycki P, et al. Epidemiological studies in Poland on effect of physical activity of pregnant women on the health of offspring and future generations - adaptation of the hypothesis development origin of health and diseases. Ann Agric Environ Med. 2012; 19(2): 315-326, indexed in Pubmed: 22742808.

10. Suliga E, Sobaś K, Król G. Validation of the Pregnancy Physical Activity Questionnaire (PPAQ). Medical Studies. 2017; 1: 40-45, doi: $10.5114 / \mathrm{ms} .2017 .66955$.

11. Chasan-Taber L, Schmidt MD, Chasan-Taber L, et al. Development and validation of a Pregnancy Physical Activity Questionnaire. Med Sci Sports Exerc. 2004; 36(10): 1750-1760, indexed in Pubmed: 15595297.

12. Matsuzaki M, Haruna $M$, Ota $E$, et al. Reliability and validity of the Vietnamese version of the Pregnancy Physical Activity Questionnaire (PPAQ). Southeast Asian JTrop Med Public Health. 2008; 39(3): 562-570, indexed in Pubmed: 18564699.

13. Shiraishi M, Haruna M, Matsuzaki M, et al. Translation and cross-cultural adaptation of the Pregnancy Physical Activity Questionnaire (PPAQ) to Japanese. Biosci Trends. 2010; 4(4): 170-177, indexed in Pubmed: 20811136.

14. Matsuzaki M, Haruna M, Nakayama K, et al. Adapting the Pregnancy Physical Activity Questionnaire for Japanese pregnant women. J Obstet Gynecol Neonatal Nurs. 2014; 43(1): 107-116, doi: 10.1111/15526909.12267, indexed in Pubmed: 24428147.

15. Chandonnet N, Saey D, Alméras N, et al. French Pregnancy Physical Activity Questionnaire compared with an accelerometer cut point to classify physical activity among pregnant obese women. PLoS One. 2012; 7(6): e38818, doi: 10.1371/journal.pone.0038818, indexed in Pubmed: 22701717.

16. Ainsworth BE, Haskell WL, Whitt MC, et al. Compendium of physical activities: an update of activity codes and MET intensities. Med Sci Sports Exerc. 2000; 32(9 Suppl): S498-S504, indexed in Pubmed: 10993420.

17. Gaston A, Cramp A. Exercise during pregnancy: a review of patterns and determinants. J Sci Med Sport. 2011; 14(4): 299-305, doi: 10.1016/j. jsams.2011.02.006, indexed in Pubmed: 21420359.

18. Fell DB, Joseph KS, Armson BA, et al. The impact of pregnancy on physical activity level. Matern Child Health J. 2009; 13(5): 597-603, doi: 10.1007/s10995-008-0404-7, indexed in Pubmed: 18719984.

19. Hegaard H, Damm P, Hedegaard M, et al. Sports and Leisure Time Physical Activity During Pregnancy in Nulliparous Women. Maternal and Child Health Journal. 2011; 15(6): 806-813, doi: 10.1007/s10995-010-0647-y.

20. Duncombe $D$, Wertheim $\mathrm{EH}$, Skouteris $\mathrm{H}$, et al. Factors related to exercise over the course of pregnancy including women's beliefs about the safety of exercise during pregnancy. Midwifery. 2009; 25(4): 430-438, doi: 10.1016/j.midw.2007.03.002, indexed in Pubmed: 18063253.

21. Tavares J, Melo A, Amorim M, et al. Padrão de atividade física entre gestantes atendidas pela estratégia saúde da família de Campina Grande - PB. Revista Brasileira de Epidemiologia. 2009; 12(1): 10-19, doi: 10.1590/s1415-790x2009000100002.

22. Charzewski J. Aktywność sportowa Polaków. Centralny Ośrodek Sportu. Resortowe Centrum Metodyczno-Szkoleniowe Kultury Fizycznej i Sportu, Warszawa 1997.

23. Eurobarometer 334/72.3. Sport i aktywność fizyczna Bruksela, 2011.

24. Evenson KR, Moos MK, Carrier K, et al. Perceived barriers to physical activity among pregnant women. Matern Child Health J. 2009; 13(3): 364-375, doi: 10.1007/s10995-008-0359-8, indexed in Pubmed: 18478322.

25. Cramp AG, Bray SR. A prospective examination of exercise and barrier self-efficacy to engage in leisure-time physical activity during pregnancy. Ann Behav Med. 2009; 37(3): 325-334, doi: 10.1007/s12160-009-9102-y, indexed in Pubmed: 19499279.

26. Szymanski LM, Satin AJ. Exercise during pregnancy: fetal responses to current public health guidelines. Obstet Gynecol. 2012; 119(3): 603-610, doi: 10.1097/AOG.0b013e31824760b5, indexed in Pubmed: 22314872.

27. ACOG Committee Opinion No. 650: Physical Activity and Exercise During Pregnancy and the Postpartum Period. Obstet Gynecol. 2015; 126(6): e135-e142, doi: 10.1097/AOG.0000000000001214, indexed in Pubmed: 26595585.

28. Nowakowska-Głąb A, Maniecka-Bryła I. Zależność między wykonywaną pracą a jakością życia związaną ze zdrowiem kobiet ciężarnych. Medycyna Pracy. 2011; 62(6): 601-607.

29. Jurewicz J, Hanke W, Makowiec-DąbrowskaT. Wpływ ciężkości pracy kobiet ciężarnych mierzony za pomocą wydatku energetycznego na mase urodzeniową noworodków. Ginekologia Polska. 2006; 77(7): 537-542. 